\title{
Macroeconomic Forces and Stock Prices: Some Empirical Evidence from Saudi Arabia
}

\author{
Lakshmi Kalyanaraman $^{1}$ \& Basmah Al Tuwajri ${ }^{1}$ \\ ${ }^{1}$ King Saud University, Riyadh, Saudi Arabia \\ Correspondence: Lakshmi Kalyanaraman, Professor, King Saud University, Riyadh, Saudi Arabia. E-mail: \\ kaylakshmi@gmail.com
}

Received: November 20, 2013

Accepted: December 15, $2013 \quad$ Online Published: January 10, 2014

doi:10.5430/ijfr.v5n1p81

URL: http://dx.doi.org/10.5430/ijfr.v5n1p81

\begin{abstract}
This paper examines if there exists a long run relationship among five macroeconomic variables, consumer price index, industrial output, money supply, exchange rate, oil prices along with the global stock prices proxy Standard and Poor 500 index and Saudi all share stock index. Time series analysis is applied using monthly data from January 1994 to June 2013. Application of Johansen cointegration test finds the existence of a long run relationship among the chosen variables. All macroeconomic variables are found to impact stock prices. Standard and Poor 500 index does not affect Saudi stock prices. Vector error correction model shows the presence of long run causality from the explanatory variables to the stock prices. Short run causality test finds a two-way causality between stock prices and oil prices. Impulse response function shows that industrial production shocks pushes up stock prices while consumer price index shocks pulls it down. Variance decompositions show that historical stock prices are the major driver of Saudi stock prices. This implies that Saudi stock market follows weak form of market efficiency. The results of this paper have important implications for the investors in Saudi stock market.
\end{abstract}

Keywords: macroeconomic variables, cointegration, Saudi Arabia, stock prices, time-series

\section{Introduction}

According to the international capital asset pricing model developed by Solnik (1983), asset returns are determined by a single global factor. This model puts forth that if the markets are globally integrated, asset returns are determined by a single priced global factor. Two underlying assumptions for the validity of this model are the world benchmark portfolio must be mean-variance efficient and markets should be integrated. Harvey (1995) produces evidence that questions the mean-variance efficiency of MSCI world index in the context of emerging markets. Research shows that emerging stock markets are less than perfectly integrated. (Bekaert and Harvey 1995). In less than perfectly integrated emerging markets, a number of pricing factors become relevant. According to the multifactor model, variables that affect future investment opportunity set or the consumption-investment decision are priced factors in equilibrium. (Merton 1973) Such factors claim a risk premia in a risk-averse economy. The co-movement of share prices of all companies suggests that there are some exogenous variables which have a market-wide impact. Theories propose a relationship between macroeconomic variables and stock market returns. (Mandelker and Tandon 1985, Boudoukh and Richardson 1993). In the context of arbitrage pricing model, macroeconomic factors are used as a measure of economy wide risk factors. (Burmeister and McElroy 1988)

Another way of explaining the impact of macroeconomic factors on the stock prices is the present value model framework. Current stock price is determined by expected future cash flows and the discount rate. All macroeconomic factors that affect the expected future cash flows or the discount rate are bound to impact the share price.

Empirical works try to figure out which specific macroeconomic variables have a bearing on share prices and the nature of their influence. According to present value model, current stock price is determined by expected future cash flows and the discount rate. All macroeconomic factors that affect the expected future cash flows or the discount rate are bound to impact the share price. However, there is no decisive theory that suggests a list of macroeconomic variables that could affect share prices. Basis for the selection of macroeconomic variables is based on intuitive finance theory. (McMillan 2010) 
This research aims to answer the following questions.

1). Is there a long run equilibrium relationship between macroeconomic variables and stock prices in Saudi Arabia?

2). Is there causality between macroeconomic variables and share prices in Saudi Arabia?

3). How do share prices respond to the shocks in any of the macroeconomic variables studied?

Though there have been many empirical works carried out on the relationship between macroeconomic variables and stock prices in the developed markets, research on emerging markets is just evolving. Stock prices in emerging markets are not tied to the economic fundamentals. (Gunasekarage et al. 2004) Risks and returns in these markets are higher than those of developed markets. (Harvey 1995) It becomes important to examine which macroeconomic forces cause this higher risk and returns.

As far as we know, there is just one study carried out till now in the context of Saudi Arabia (Alshogeathri 2011), in spite of it being the largest in the gulf region. The study analyses the long run relationship among consumer price index, money supply, industrial output, oil prices, exchange rate and global market prices on the Saudi stock prices.

The paper proceeds along the following lines. Section 2 presents the review of literature, Section 3 discusses methodology, Section 4 discusses the empirical results and Section 5 offers conclusions.

\section{Previous Works}

Various empirical works have been carried out focussing on the influence of macroeconomic variables on developed stock markets. (See for example Hondroyiannis and Papapetrou 2001). More recent works, however, concentrate on analysing the emerging markets. This section reviews a few studies carried out in the context of emerging stock markets.

Mukherjee and Naka (1995) concluded that cointegrating relationship existed between exchange rate, inflation, money supply, real economic activity, long-term government bond rate and call money rate and Japanese stock market.

Abdalla and Murinde (1997) analysed the interactions between exchange rates and stock prices in emerging market economies including India, Korea, Pakistan and Philippines applying cointegration techniques and Granger causality tests. On the basis of the analysis of data relating to January 1985 to July 1984, they concluded that there is a unidirectional causality from exchange rates to stock prices in all the sample countries other than Philippines.

Muradoglu et al. (2000) examined the causal relationship between macroeconomic variables and stock returns in 19 emerging market economies using Granger causality test. Data from January 1976 to December 1997 on exchange rates, interest rates, inflation rate, industrial production and return from global index was studied. Results from Granger causality test discovered bidirectional causality relationship between stock returns and macroeconomic variables.

The study by Fifield et al. (2002) is carried out in 13 emerging stock markets. The work investigates the extent to which global and local economic factors explain returns in emerging stock markets. Using principal components analysis the economic factors are determined. The local economic variables studied are GDP, inflation, money and interest rates. The global variables included in the study are world industrial production and world inflation. The results indicate that while world factors are significant in explaining the emerging stock markets returns, local factors also play a very crucial role.

Maysami et al. (2004) examined the long term equilibrium relationships between a few macroeconomic variables and the Singapore stock market index and various sectoral indices. They found that Singapore stock market and property index form cointegrating relationship with changes in the short and long term interest rates, industrial production, price level, exchange rate and money supply.

Gunasekarage et al. (2004) analysed the influence of money supply, Treasury bill rate, consumer price index and exchange rate on stock market equity values in Sri Lanka. They analysed monthly time series data for the period from January 1985 to December 2001 by applying cointegration and vector error correction model. Their test results show that macroeconomic variables have a significant influence on stock market.

Alshogeathri (2011) investigates the long run and short run relationships between Saudi stock market returns and eight macroeconomic variables; two different measures of money supply, short-term interest rates, consumer price index, bank credit, world crude oil prices, exchange rate and Standard and Poor 500 index as a proxy for the influence of the US stock on the local stock market. He applied a wide range of vector auto regression and generalized autoregressive conditional heteroskedasticity model to analyse monthly data from January 1993 to 
December 2009. He found that there is a positive relationship long run relationship between the Saudi stock price index and M2 money supply, short term interest rate, inflation and the US stock market. He discovered significant unidirectional short run causal relationships between Saudi stock market returns and money supply and inflation.

El-Nader and Alraimony (2012) examine the impact of macroeconomic factors on Amman stock market returns employing monthly data between 1991 and 2010. The results of the ARCH (1) estimation shows that real money supply, consumer price index, real exchange rate, weighted average interest rates on loans and advances and dummy variable has a negative role on Amman stock exchange returns. Real gross domestic product has a positive impact.

As mentioned earlier, research on if the macroeconomic variables influence the stock returns in emerging markets are more recent. There have not been many studies carried out in the context of Saudi Arabia, in spite of it being one of the largest markets in the Gulf region. This study intends to bridge this gap in literature.

\section{Methodology}

Time series analysis is applied to evaluate the dynamic relationship between equity prices and macroeconomic variables in Saudi Arabia. The study applies cointegration analysis in order to study the long-run relationship between stock prices and macroeconomic variables.

$$
\ln T A S I=f(\ln C P I, \operatorname{lnIP}, \ln M S, \ln E X, \ln O I L, \ln S P)
$$

The first step in the analysis is the application of unit root tests to check stationary properties of the variables. In stationary time series, shocks will be temporary and over time the effects will be removed and the series will revert back to their long-run mean values. Non-stationary time series has mean and variance that will depend on time. Non-stationary cointegrated variables are unstable in level exhibiting mean-reverting spreads that force the variables to move around common stochastic trends. Application of cointegration test requires pre-testing of data to check is they are integrated of the same order. The study uses Augmented Dickey-Fuller (ADF) test to check if the variables in the model are integrated of the same order. Optimal lag lengths for the ADF test are decided on the basis of Alkaike information criterion.

After ensuring that the variables are I(1), cointegration procedure is applied. Cointegration allows the data representation to take advantage of its theoretical properties. The methodology recognises that some variables drift together. Two popular cointegration techniques used in the empirical works are Engle and Granger (1987) test and Johansen-Juselius (JJ) (1990) test. This study employs JJ test because of its merits over EG test. EG test is more appropriate for bivariate analysis as it cannot detect multiple cointegrating relationships. JJ test is suitable for multivariate analysis. EG is a two-step estimator. The first step generates the residual series and the second step estimates a regression for this series to check if the series is stationary or not. Any error in the first step gets carried over to the second step. This study applies Johansen test of cointegration.

Causality can be divided into long-run and short-run. Long-run causality is determined by the error correction term. A significant negative error correction term indicates that there is long-run causality from the explanatory variables to the dependent variable. However, in a multivariate analysis, it is difficult to figure out which explanatory variable is responsible for the causality reflected in the error correction term. Short-run causality is determined by error correction terms and lagged term of each explanatory variable simultaneously by a Wald $\chi^{2}$ test. It is possible to have evidence of long-run causality and not on short-run causality and vice versa. Hence, both the tests are carried out.

The study relies on Impulse Response Function (IRF) and Variance Decomposition (VDC) to analyse the dynamic properties of the variables. IRFs measure the effect of a shock to an endogenous variable on itself or on another endogenous variable. IRF is used by the study to analyse how sensitive are the Saudi stock prices to the changes in each of the chosen macroeconomic variable. The variance decomposition (VDC) measures the fraction of the variance of an endogenous variable that can be attributed to shocks to itself or to another endogenous variable. VDC breaks down the variations of stock prices sensitivity to each macroeconomic variable.

\subsection{Variables}

The variables included and data used in the study are described below.

\subsubsection{Tadawul All Share Index (TASI)}

TASI is disseminated by Saudi stock exchange. It was developed with a base value of 1000 in 1985 . The index includes the share prices of all the listed companies. TASI excludes shares owned by government and institutions, the foreign partner if he or she is not permitted to sell without the prior approval of the supervision authority, founder partner during restriction period and owners of $10 \%$ or more from the shares of the listed company at the Saudi stock 
exchange member firm. (Tadawul website 2013) TASI is used as a proxy for Saudi Arabian stock prices. As the index includes all the listed companies, it can be expected to reflect the macroeconomic variables of the economy.

\subsubsection{Money Supply}

Increase in money supply is expected to increase the investible funds in hands of investors and push up the demand for stocks. This should result in an increase in stock prices. Tightening of money supply will increase the real interest rate and will prompt investors to increase the discount rate. This decreases the present value of the future cash flows from the stock investment and result in a fall in stock prices.

Mukherjee and Naka (1995) argue that the impact of money supply on stock prices is an empirical question. An increase in money supply will result in inflation and increased discount rate. As a result, the stock prices will fall (Fama 1981). This negative impact of increased money supply may be set off by the economic stimulus provided by money growth. Increased money supply may induce corporate investments and may increase future cash flows and stock prices.

M2 is used as the measure of money supply. An increase in M2 will provide the required liquidity for buying stock.

\subsubsection{Inflation}

Relationship between inflation and stock prices is under debate. Some argue that stock investment provides an effective hedge against inflation. (Bodie 1976) This idea is originally put forth by Fisher (1930). According to Fisher effect, higher inflation will increase the nominal stock return keeping the real stock return intact.

Others support an inverse relationship between inflation and stock prices. (See for example Fama 1981) Investors shift their investment to real assets in case of high inflation and share prices fall. Increase in inflation will lead to economic policies focusing on the tightening of money supply. This increases the nominal interest rate. If the increase in discount rate is coupled with the increase in the cash flows at the same rate, stock prices will fall. This study uses consumer price index to measure inflation.

\subsubsection{Oil Prices}

Impact of oil prices on stock prices depends on if the economy that is being studied is an oil importer or oil exporter.

Empirical works carried out in the context of oil importing countries show that oil price variations have strong and negative consequences on the economy. Research carried out in the context of oil exporting countries throw up different results. Bjornland (2008) analyses the effect of oil price shocks on stock returns in Norway, an oil exporting country. He finds that a $10 \%$ increase in oil price increases stock returns by $2.5 \%$ and the effect fades away later. Norwegian economy is found to face an increase in aggregate wealth and demand in response to higher oil prices. Arouri et al. (2009) use linear and nonlinear models to investigate the responses of stock markets in GCC countries to oil price shocks. Their results show that stock market returns significantly react to oil price changes in Qatar, Oman, Saudi Arabia and UAE.

Oil prices have particular relevance to Saudi Arabia. It is an oil based economy being the world's largest producer and exporter of oil. Oil represents $90 \%$ of total export earnings, $80 \%$ of government's revenue and $45 \%$ of its GDP. Fluctuations in oil prices affect the major economic variables of the country.

\subsubsection{Exchange Rate}

The two most important approaches to evaluating the relationship between exchange rate and stock prices are goods market approach and portfolio balance approach. Goods market approach argues that the changes in the exchange rates affect the relative competitiveness of the goods of an economy in the international context. Depreciation in the domestic currency makes local firms more competitive and increases exports and profits from exports. Increase in cash flows from equity investment pushes up the stock prices. Dornbusch and Fischer (1980) suggest a negative relationship between exchange rates and stock prices. However, this argument depends on the importance of international trade on the domestic economy and the imports and exports of listed firms.

Portfolio balance approach suggests a positive relationship between exchange rates and stock prices. Stock market appreciation attracts higher foreign capital flows. This results in the domestic currency appreciation. Stock market fall will have the opposite effect. Capital account transactions determine the relationship between exchange rate and stock prices. (Frankel 1993) This approach is based on the domestic and foreign assets held by the investors.

Saudi Arabia is an open economy with no restrictions on capital flows. Saudi Arabia's merchandise trade is $82.6 \%$ of its Gross Domestic Product as of 2011. Net inflow of foreign direct investment is \$16,308 million as of 2011. (World Bank, 2013) These figures show to prove that Saudi Arabia has strong global links. Exchange rates are bound to 
impact stock prices. Nominal effective exchange rate is used to study the relationship between exchange rate and stock prices.

\subsubsection{Industrial Production}

Industrial production measures the real output of the industrial sector of the economy. Industrial production results in increased economic activity and higher earnings for companies. Higher expected earnings pushes up stock prices and returns. Chen, Roll and Ross (1986) produce evidence to show that future growth in industrial production explains stock returns. The impact is significantly positive. Tainer (1993) argues that industrial production index rises during economic expansion and falls during recession. This study includes level of industrial output.

\subsubsection{Standard and Poor's 500 Index}

Increased integration of global financial markets pose a challenge to the investors in understanding how the global equity markets impact the domestic market prices. Standard and Poor's 500 index is used as a proxy for global equity prices.

Saudi Arabia's currency is pegged to American dollar since 1986. With no great restrictions on capital and current account transactions, American markets offer attractive alternative investment avenues for Saudi investors. This variable is included in the study to assess the relationship between global stock prices and domestic stock prices.

\subsection{Data}

Data relating to all the variables are monthly frequency running from January 1994 to June 2013. Data is obtained from Compustat and Bloomberg. All variables are in their logarithmic form. Table 1 gives the descriptive statistics for the variables.

Table 1. Descriptive statistics for the variables in logarithmic form

\begin{tabular}{crrrrrrr}
\hline & \multicolumn{1}{c}{ TASI } & \multicolumn{1}{c}{ CPI } & \multicolumn{1}{c}{ IP } & \multicolumn{1}{c}{ MS } & EX & \multicolumn{1}{l}{ OIL } & \multicolumn{1}{l}{ SP } \\
\hline Mean & 8.22 & 4.68 & 9.62 & 6.06 & 4.66 & 3.64 & 6.95 \\
Median & 8.36 & 4.62 & 9.59 & 5.80 & 4.65 & 3.43 & 7.04 \\
Maximum & 9.88 & 4.99 & 9.93 & 7.16 & 4.86 & 4.94 & 7.40 \\
Minimum & 7.04 & 4.56 & 9.40 & 5.43 & 4.51 & 2.35 & 6.10 \\
Standard & 0.77 & 0.13 & 0.09 & 0.56 & 0.09 & 0.73 & 0.32 \\
deviation & & & & & & & \\
Skewness & 0.09 & 1.20 & 0.97 & 0.56 & 0.54 & 0.15 & -1.19 \\
Kurtosis & 1.68 & 2.91 & 4.75 & 1.79 & 2.30 & 1.62 & 3.59 \\
Jarque-Bera & $17.39^{*}$ & $56.09^{*}$ & $66.15^{*}$ & $26.82^{*}$ & $16.17^{*}$ & $19.37^{*}$ & $59.05^{*}$ \\
\hline
\end{tabular}

Note: $1 . *$ implies statistical significance at $1 \%$ level

\section{Empirical Results}

Table 1 describes the results of ADF and PP unit root tests. Both tests confirm that the variables chosen for the study are non-stationary in level and stationary after first differencing. We can now apply cointegration test.

Table 2

\begin{tabular}{|c|c|c|}
\hline \multicolumn{3}{|c|}{ ADF Test Results } \\
\hline \multirow[t]{2}{*}{ Variables } & \multicolumn{2}{|c|}{ ADF t-statistic } \\
\hline & Level & First difference \\
\hline TASI & $-1.517495(1)$ & $-11.95597(0)$ \\
\hline CPI & $0.048902(3)$ & $-6.058366(2)$ \\
\hline IP & $-3.184285(1)$ & $-14.48883(1)$ \\
\hline MS & $-1.407178(0)$ & $-15.73069(0)$ \\
\hline EX & $-1.803989(1)$ & $-10.05484(1)$ \\
\hline OIL & $-3.140375(1)$ & $-13.25163(0)$ \\
\hline SP & $-1.914933(0)$ & $-13.68880(0)$ \\
\hline Test critical values: $1 \%$ & -3.998104 & -3.998457 \\
\hline $5 \%$ & -3.429313 & -3.429484 \\
\hline $10 \%$ & -3.138142 & -3.138243 \\
\hline
\end{tabular}




\subsection{Results of Optimal Lag Length Tests}

An appropriate lag length has to be chosen before applying cointegration technique. Model will be misspecified if the lag length is too small and is over parameterized if the number of lags is too large. The study applies lag order selection based on the LR test and information criteria such as Akaike Information Criterion (AIC), Final Prediction Error (FPE), Schwarz Criterion (SC), Hannan and Quinn Criterion (HQ). The suggested lag lengths by the tests differ. SIC and HQ suggest a lag length of 1, while FPE and AIC suggest 2 lag lengths. LR test recommends a lag length of 5 .

Table 3. VAR lag order selection criteria

\begin{tabular}{lllllll}
\hline Lag & Log-Likelihood & LR & FPE & AIC & SIC & HQ \\
\hline 0 & 828.6268 & NA & $1.44 \mathrm{e}-12$ & -7.402043 & -7.294751 & -7.358725 \\
1 & 3476.130 & 96.51506 & $9.80 \mathrm{e}-23$ & -30.81198 & $-29.95365^{*}$ & $-30.46544^{*}$ \\
2 & 3527.884 & 96.51506 & $9.57 \mathrm{e}-23^{*}$ & $-30.83679^{*}$ & -29.22742 & -30.18703 \\
3 & 3570.444 & 76.68427 & $1.02 \mathrm{e}-22$ & -30.77877 & -28.41836 & -29.82578 \\
4 & 3599.142 & 49.89877 & $1.23 \mathrm{e}-22$ & -30.59587 & -27.48442 & -29.33966 \\
5 & 3640.275 & $68.92548^{*}$ & $1.33 \mathrm{e}-22$ & -30.52500 & -26.66250 & -28.96556 \\
6 & 3667.011 & 43.11479 & $1.65 \mathrm{e}-22$ & -30.32442 & -25.71088 & -28.46176 \\
7 & 3695.262 & 43.77657 & $2.03 \mathrm{e}-22$ & -30.13750 & -24.77292 & -27.97161 \\
8 & 3735.061 & 59.16033 & $2.27 \mathrm{e}-22$ & -30.05460 & -23.93898 & -27.58550 \\
9 & 3772.974 & 53.96559 & $2.60 \mathrm{e}-22$ & -29.95472 & -23.08805 & -27.18238 \\
10 & 3810.389 & 50.89910 & $3.02 \mathrm{e}-22$ & -29.85036 & -22.23265 & -26.77480 \\
11 & 3847.520 & 48.16912 & $3.55 \mathrm{e}-22$ & -29.74342 & -21.37467 & -26.36464 \\
12 & 3890.704 & 53.29916 & $4.01 \mathrm{e}-22$ & -29.69102 & -20.57124 & -26.00902 \\
\hline
\end{tabular}

* indicates lag order selected by the criterion

LR: Sequential modified LR test statistic (each test at $5 \%$ level)

FPE: Final prediction error

AIC: Akaike information criterion

SC: Schwarz information criterion

To handle this problem of varying lag length recommendations, VAR model including all variables in levels is estimated for each of the lag length suggested by different criteria is run and VAR residual serial correlation LM test is carried out to choose the appropriate lag length. Lag length of 5 suggested by LR test is recommended by this analysis.

Table 4. VAR residual serial correlation LM test

\begin{tabular}{lllllll}
\hline \multirow{2}{*}{ Lags } & \multicolumn{2}{l}{ Panel (a): One Lag } & \multicolumn{2}{l}{ Panel (b): Two Lags } & \multicolumn{2}{l}{ Panel (c): Five Lags } \\
\cline { 2 - 7 } & LM-Stat & P-values* & LM-Stat & P-values* & LM-Stat & P-values* \\
\hline 1 & 99.86925 & 0.0000 & 71.96128 & 0.0180 & 43.53796 & 0.6934 \\
2 & 65.72953 & 0.0554 & 70.77359 & 0.0225 & 41.44927 & 0.7696 \\
3 & 60.36486 & 0.1280 & 59.53310 & 0.1440 & 41.29865 & 0.7747 \\
4 & 68.44192 & 0.0346 & 71.66067 & 0.0190 & 50.89623 & 0.3988 \\
5 & 44.20235 & 0.6677 & 39.61891 & 0.8283 & 42.75531 & 0.7230 \\
6 & 45.44394 & 0.6181 & 43.10830 & 0.7098 & 45.04163 & 0.6343 \\
7 & 51.72516 & 0.3679 & 49.86675 & 0.4387 & 54.25049 & 0.2812 \\
8 & 45.41328 & 0.6193 & 40.58519 & 0.7984 & 47.14548 & 0.5486 \\
9 & 44.17496 & 0.6687 & 48.77115 & 0.4823 & 43.55118 & 0.6929 \\
10 & 43.07643 & 0.7110 & 37.14110 & 0.8929 & 38.37446 & 0.8630 \\
11 & 73.82977 & 0.0125 & 63.28196 & 0.0825 & 56.41588 & 0.2174 \\
12 & 63.95314 & 0.0742 & 60.21895 & 0.1307 & 56.55022 & 0.2138 \\
\hline
\end{tabular}

* P-values based on $\chi^{2}$ asymptotic (large sample) distribution with 49 degree of freedom (df) 


\subsection{Results of Cointegration Test}

Trace test indicates 4 cointegrating equations and Max-eigenvalue test indicates 1 cointegrating equation at 0.05 level. Both the tests are based on the likelihood ratio. The results of trace test and max-eigenvalue test differ. We choose to adopt the results of Max-eigenvalue test because the $\lambda_{\max }$ test has a sharper alternative hypothesis. According to Enders (2003), $\lambda_{\max }$ test is usually preferred for deciding on the number of cointegrating vectors. This notion is supported by Banerjee et. $\mathrm{Al}$ (1993). There is at least one cointegrating equation. It can be inferred that macroeconomic variables in the system share a long-run relationship. Each variable in the system tends to adjust to remove short-run deviations from the long-run equilibrium state.

Table 5. Johansen test for multiple co-integrating vectors

\begin{tabular}{|c|c|c|c|c|}
\hline \multicolumn{5}{|c|}{ Panel (a): Unrestricted Cointegration Rank Test based on Trace Statistic Test } \\
\hline $\begin{array}{l}\text { Hypothesized } \\
\text { No. of CEs }\end{array}$ & Eigenvalue & Trace Statistic & 0.05 Critical Value & P-values** \\
\hline None* & 0.199618 & 166.2380 & 125.6154 & 0.0000 \\
\hline At most $1 *$ & 0.160879 & 115.4702 & 95.75366 & 0.0011 \\
\hline At most $2 *$ & 0.100154 & 75.47892 & 69.81889 & 0.0165 \\
\hline At most $3 *$ & 0.096473 & 51.41771 & 47.85613 & 0.0223 \\
\hline At most 4* & 0.072349 & 28.28735 & 29.79707 & 0.0739 \\
\hline At most 5 & 0.046100 & 11.16450 & 15.49471 & 0.2016 \\
\hline At most 6 & 0.001769 & 0.403802 & 3.841466 & 0.5251 \\
\hline \multicolumn{5}{|c|}{ Panel (b): Unrestricted Cointegration Rank Test based on Maximum Eigenvalue Test } \\
\hline $\begin{array}{l}\text { Hypothesized } \\
\text { No. of CEs }\end{array}$ & Eigenvalue & Max-Eigen Statistic & 0.05 Critical Value & P-values** \\
\hline None* & 0.199618 & 50.76783 & 46.23142 & 0.0153 \\
\hline At most 1 & 0.160879 & 39.99124 & 40.07757 & 0.0511 \\
\hline At most 2 & 0.100154 & 24.06122 & 33.87687 & 0.4511 \\
\hline At most 3 & 0.096473 & 23.13036 & 27.58434 & 0.1680 \\
\hline At most 4 & 0.072349 & 17.12284 & 21.13162 & 0.1663 \\
\hline At most 5 & 0.046100 & 10.76070 & 14.26460 & 0.1666 \\
\hline At most 6 & 0.001769 & 0.403802 & 3.841466 & 0.5251 \\
\hline
\end{tabular}

* denotes rejection of the hypothesis at the 0.05 level

** MacKinnon-Haug-Michelis (1999) p-values

An OLS estimation of the cointegrating equation is given below. If the variables are not cointegrated, the results obtained from regression are spurious. However, if the variables are cointegrated, then OLS regression yields super-consistent estimators for the cointegrating parameters. All the variables excepting S\&P 500 index are found to be statistically significant in explaining the variations in the stock prices.

Table 6. Dependent Variable: TASI

Method: Least Squares

\begin{tabular}{crcrr}
\hline Variable & Coefficient & \multicolumn{1}{c}{ Std. Error } & t-Statistic & \multicolumn{1}{c}{ Prob. } \\
\hline CPI & -6.545263 & 0.287744 & -22.74682 & 0.0000 \\
\hline IP & 1.581977 & 0.174502 & 9.065652 & 0.0000 \\
\hline MS & 1.602466 & 0.106945 & 14.98399 & 0.0000 \\
\hline EX & 0.470624 & 0.221986 & 2.120060 & 0.0351 \\
\hline OIL & 0.553468 & 0.056686 & 9.763768 & 0.0000 \\
\hline SP & 0.036269 & 0.065711 & 0.551940 & 0.5815 \\
\hline C & 9.458629 & 2.147001 & 4.405508 & 0.0000 \\
\hline R-squared & 0.942777 & Mean dependent var & & 8.221625 \\
\hline Adjusted R-squared & 0.941264 & S.D. dependent var & & 0.772693 \\
\hline S.E. of regression & 0.187265 & Akaike info criterion & & -0.483122 \\
\hline Sum squared resid & 7.960509 & Schwarz criterion & & -0.379758 \\
\hline Log likelihood & 63.52528 & Hannan-Quinn criter. & & -0.441446 \\
\hline F-statistic & 623.3222 & Durbin-Watson stat & & 0.322565 \\
\hline Prob(F-statistic) & 0.000000 & & \\
\hline
\end{tabular}


Saudi stock prices and inflation as measured by consumer price index have inverse relationship. This finding supports the notion that investors do not consider equity as a hedge against inflation. They probably shift their investment to real assets in the presence of inflation. This finding is in line with some of the earlier works that bring out a negative relationship between stock prices and inflation. (See for example Fama 1981)

Industrial production and stock prices are positively related. Increase in the real economic activity of the economy brings in optimism about the increased return on investment on equity and pushes up stock prices. This result is in line with the findings of Humpe and Macmillan (2009).

Increase in money supply increases the demand for equity investment and increases the stock prices. Money supply and stock prices share a positive relationship. This is consistent with the results of many earlier works such as Bulmash and Trivoli. (1991)

Exchange rate and stock prices are also positively related. Saudi Arabia has no restrictions on capital account convertibility. Balance of foreign assets of Saudi Arabia was at SAR 3.07 trillion as at the end of 2011 recording a growth of $15.9 \%$ over the previous year. Direct investment held abroad was at SAR 112.3 billion, an increase of $12.9 \%$ over the previous year. Portfolio investment in debt securities and equity securities were at SAR 231.1 billion and SAR 376 billion respectively during the same year. The positive relationship between exchange rate and stock prices may indicate the mobility of investible funds across borders.

Saudi Arabia is an oil exporting economy. Its oil exports have been registering an increase over the years. As of 1994, the country exported 2,275.27 million barrels. In 2012, this figure is at 2,783.77 million barrels. Its economic development is largely driven by revenue from oil exports. Oil prices and stock prices have a positive relationship. This finding supports the results of the study by Gjerde and Saettem (1999) on Norway.

\subsection{Results of Error Correction Mechanism}

The estimated coefficient of the error correction term has a negative sign and is significant. This reconfirms that the variables in the system are cointegrated. Coefficient of the error correction term indicates the speed of adjustment to the long-run equilibrium whenever there are deviations. When the stock prices deviate from their long-run equilibrium in the short-run, it is corrected and the long-run equilibrium is brought back. The estimated error correction coefficient of -0.027689 shows that around $2.76 \%$ of the short-run deviations are corrected every month to bring it back to the level of long-run equilibrium. TASI is extremely slow in correcting the disequilibrium in the system. About $1 \%$ of the disequilibrium is corrected every month by changes in money supply. Changes in all other variables contribute less than $1 \%$ towards disequilibrium correction every month. Results of VECM show that chosen variables are cointegrated and a long-run equilibrium relationship exists between the variables. Whenever the variables drift from the long-run equilibrium, the adjustment process in the short-run corrects the disequilibrium and prevents the variables from drifting away from each other.

Table 7. Multivariate VECM causality test

\begin{tabular}{|c|c|c|c|c|c|c|c|c|}
\hline \multirow{2}{*}{$\begin{array}{l}\text { Dependent } \\
\text { Variable }\end{array}$} & \multicolumn{7}{|c|}{ Independent Variables } & \multirow[b]{2}{*}{ ECT } \\
\hline & $\Delta \mathrm{TASI}$ & $\Delta \mathrm{CPI}$ & $\Delta \mathrm{IP}$ & $\Delta \mathrm{MS}$ & $\Delta \mathrm{EX}$ & $\Delta \mathrm{OIL}$ & $\Delta \mathrm{SP}$ & \\
\hline \multirow[t]{2}{*}{$\Delta \mathrm{TASI}$} & --- & 7.081 & 9.177 & 4.230 & 3.857 & $13.18^{*}$ & 1.722 & $-0.028^{*}$ \\
\hline & & $(0.214)$ & $(0.102)$ & $(0.516)$ & $(0.570)$ & $(0.022)$ & $(0.886)$ & $(0.002)$ \\
\hline \multirow[t]{2}{*}{$\Delta \mathrm{CPI}$} & 2.436 & ---- & 3.162 & 10.075 & 2.174 & 0.464 & 3.611 & 0.001 \\
\hline & $(0.786)$ & & $(0.675)$ & $(0.073)$ & $(0.824)$ & $(0.802)$ & $(0.601)$ & $(0.034)$ \\
\hline \multirow[t]{2}{*}{$\Delta \mathrm{IP}$} & 5.050 & 3.254 & ---- & 2.734 & 4.010 & 1.403 & 9.223 & 0.007 \\
\hline & $(0.410)$ & $(0.661)$ & & $(0.741)$ & $(0.548)$ & $(0.924)$ & $(0.100)$ & $(0.229)$ \\
\hline \multirow[t]{2}{*}{$\Delta \mathrm{MS}$} & 2.301 & 4.659 & 2.585 & ---- & 3.155 & 4.847 & 3.773 & 0.002 \\
\hline & $(0.805)$ & $(0.459)$ & $(0.764)$ & & $(0.676)$ & $(0.435)$ & $(0.582)$ & $(0.379)$ \\
\hline \multirow[t]{2}{*}{$\Delta \mathrm{EX}$} & 8.703 & $32.978^{*}$ & $15.080^{*}$ & 1.782 & ---- & $25.556^{*}$ & 7.734 & 0.008 \\
\hline & $(0.121)$ & $(0.000)$ & $(0.010)$ & $(0.878)$ & & $(0.000)$ & $(0.171)$ & $(0.000)$ \\
\hline \multirow[t]{2}{*}{$\Delta \mathrm{OIL}$} & $14.77^{*}$ & 2.476 & 7.607 & 9.590 & 3.540 & --- & 6.692 & -0.012 \\
\hline & $(0.011)$ & $(0.780)$ & $(0.179)$ & $(0.088)$ & $(0.617)$ & & $(0.245)$ & $(0.349)$ \\
\hline
\end{tabular}

Notes:

1. ECT column gives error correction term with $\mathrm{p}$ values in parenthesis

2. All other columns give $\chi^{2}$ test statistic with $p$ values in parenthesis

3. $*$ denotes significance at $5 \%$ level

Saudi stock market has two-way short run causality with oil prices. Changes in oil prices cause changes in stock prices. Similarly, Saudi stock market influences oil prices. This is in line with the finding of Malik and Hammoudeh 
(2007) who suggest that Saudi market contributes significantly to changes in the oil market. None of the other macroeconomic variables or the global prices Granger cause Saudi stock prices. Oil prices, industrial production and inflation are leading indicators of exchange rate changes in the short run. We do not expect Saudi stock prices to cause changes in the US stock prices. Hence, we did not analyse this relationship.

\subsection{Dynamic Analysis}

Impulse response functions and variance decompositions are carried out to examine how shock to the macroeconomic variables bounce back through the system. Before carrying out these analyses, it is important to ensure that the VAR model is stable. The model satisfies the stability condition, as there are no roots lying outside the unit circle in the model.

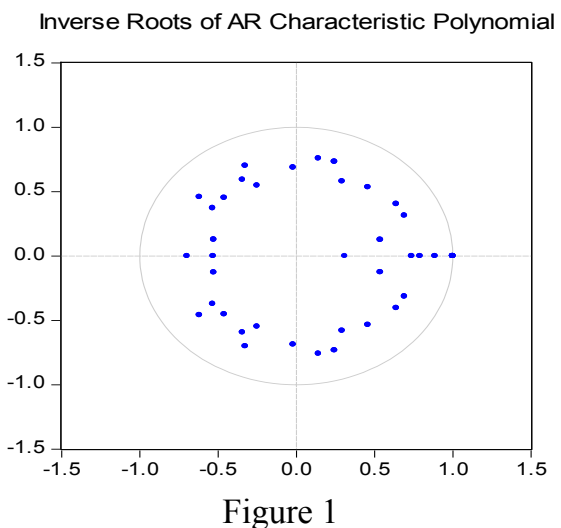

\subsection{Impulse Response Function (IRF):}

IRFs track the response of the Saudi stock prices to innovations in each of the macroeconomic variables. We can examine the magnitude, direction and length of time that stock prices are affected by a shock of a variable in the system, keeping all the other variables constant.

Accumulated Response to Cholesky One S.D. Innovations \pm 2 S.E.

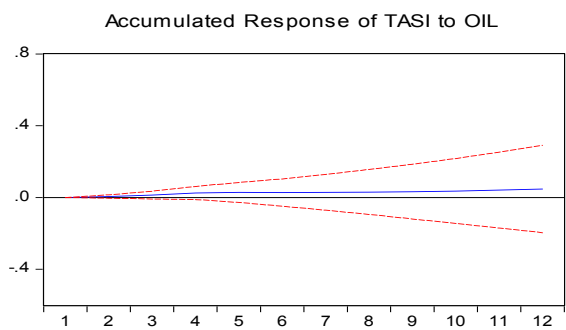

Accumulated Response of TASI to MS
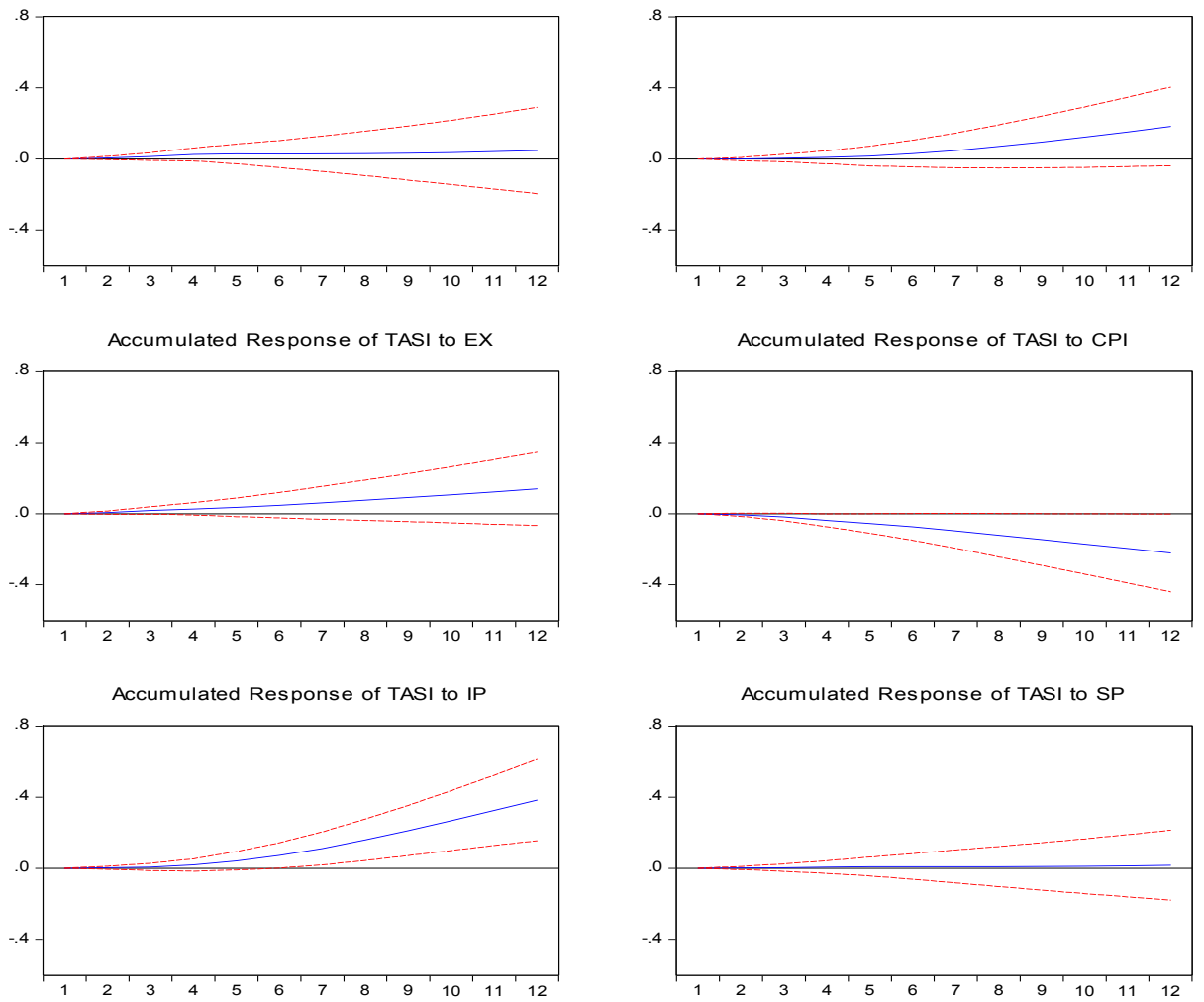

Figure 2 
Aggregate oil price shocks have no impact during the first three months and have a low impact subsequently. Money supply shocks have no impact in the short-run and have moderate effect on TASI later on. Exchange rate shocks impacts TASI after 3 months. There is statistically significant short run relationship between stock prices and inflation. Till 4 months, industrial production shocks have no effect on TASI. After the $4^{\text {th }}$ month, industrial production shocks push up TASI during the entire 24 months studied. Global stock prices shocks have no impact on Saudi stock market prices.

VDC supplements Granger causality test results by examining the out of sample causality. Variance decomposition shows the relative importance of each structural shock to the variables in the system. This function examines the dynamic interaction between Saudi stock index and the chosen variables. It shows how the variables react to their own shocks and shocks in other variables. Results are based on the pre-specified ordering of variables.

Table 8. Variance decomposition of fluctuations caused in TASI

\begin{tabular}{lllllllll}
\hline Months & S.E. & $\Delta$ TASI & $\Delta$ CPI & $\Delta$ MS & $\Delta$ IP & $\Delta$ EX & $\Delta$ OIL & $\Delta$ SP \\
\hline 1 & 0.06331 & 100.00 & 0.00 & 0.00 & 0.00 & 0.00 & 0.00 & 0.00 \\
4 & 0.15718 & 95.04 & 1.76 & 0.08 & 0.35 & 1.23 & 1.31 & 0.18 \\
8 & 0.24086 & 87.31 & 1.47 & 0.50 & 6.86 & 3.13 & 0.52 & 0.17 \\
12 & 0.31279 & 77.72 & 1.86 & 1.46 & 13.54 & 4.46 & 0.45 & 0.48 \\
16 & 0.37339 & 70.35 & 3.19 & 2.03 & 17.67 & 5.47 & 0.49 & 0.77 \\
20 & 0.42680 & 64.85 & 4.87 & 2.22 & 20.23 & 6.30 & 0.59 & 0.91 \\
24 & 0.47524 & 60.56 & 6.56 & 2.21 & 21.98 & 6.97 & 0.70 & 0.98 \\
\hline
\end{tabular}

Table 8 reports the variance decompositions for the Saudi stock market prices over the 24-months period. In the first month, as predicted, there is no contribution from the other variables to stock prices. In the fourth month, TASI shock is the main driver of TASI which is $95.04 \%$. It can be inferred that historical prices can be used for prediction. However, the effect of TASI shock on TASI slowly fades over time, though it still continues to be the most important driver. The second most important variable that influences TASI is consumer price index though it is marginal at $1.76 \%$ in the $4^{\text {th }}$ month. In the eighth month, its place is taken over by industrial production and the second most important variable becomes the nominal effective exchange rate pushing consumer price index to the third position. Over the $24^{\text {th }}$ month period, it can be seen that industrial production has a significant influence on TASI followed by nominal effective exchange rate and consumer price index. The longer the time period, higher is the impact of industrial production on stock prices. It can be inferred from this analysis that Saudi stock prices can be predicted from the historical prices.

\section{Conclusion}

The study has found that the chosen macroeconomic factors, consumer price index, industrial output, money supply, exchange rate and oil prices can explain the pricing process in the Saudi stock market. All these macroeconomic factors can be effectively used by the investors in the analysis of the return generating process. Global stock prices as measured by Standard and Poor 500 index have no impact on the stock prices. This is leads to the conclusion that Saudi stock prices are driven by domestic macroeconomic factors than global factors in the long run. This is in line with the results of many works which show that emerging market economies are less integrated with the developed markets and are less impacted by their share price movements. Historical stock prices are found to be a major driver of stock prices. This shows that Saudi stock market follows weak form of market efficiency. The results of this study have important implications for the investors. Saudi stock market investors should closely follow the macroeconomic factors in order to predict long run share prices. Historical stock prices can be used as a good predictor of future stock prices both in the short run and long run. Policy makers may minimize the fluctuations in the stock prices by controlling the relevant macroeconomic forces.

\section{References}

Abadalla, I.S.A., \& Victor, M. (1997). Exchange rate and stock price interactions in emerging financial markets: evidence on India, Korea, Pakistan and the Philippines. Applied Financial Economics, 7, 25-35. http://dx.doi.org/10.1080/096031097333826

Alshogearthi, M. (2011). Macroeconomic determinant of the stock market movement: empirical evidence from the Saudi stock market. Kansas state university. 
Arouri, M.E.H., \& Fouquau, J. (2009). On the short term influence of oil price changes on stock markets in GCC countries: linear and nonlinear analyses. Journal of Economics Bulletin, 29, 795-804.

Banerjee, A., Dolado, J., Galbraith, J.W., \& David, H. (1993). Co-integration, error correction and the econometric analysis of non-stationary data. USA: Oxford University Press. http://dx.doi.org/10.1093/0198288107.001.0001

Bekaert, G., \& Harvey, C. (1995). Time-varying world market integration. Journal of Finance, 50, 403-444. http://dx.doi.org/10.1111/j.1540-6261.1995.tb04790.x

Bjornland, H.C. (2008). Monetary policy and exchange rate interactions in a small open economy. The Scandinavian Journal of Economics, 110, 197-221. http://dx.doi.org/10.1111/j.1467-9442.2008.00532.x

Bodie, Z. (1976). Common stocks as a hedge against inflation. Journal of Finance, 31, 459-470. http://dx.doi.org/10.1111/j.1540-6261.1976.tb01899.x

Boudoukh, J., \& Richardson, M. (1993). Stock returns and inflation: a long-horizon perspective. American Economic Review, 83, 1346-1355.

Bulmash, S.B., \& Trivoli, G.W. (1991). Time-lagged interactions between stock prices and selected economic variables. Journal of Portfolio Management, 17, 61-67. http://dx.doi.org/10.3905/jpm.1991.409351

Burmeister, E., \& McElroy, M. (1988). Joint estimation of factor sensitivities and risk premia for the arbitrage pricing theory. Journal of Finance, 38, 721-735. http://dx.doi.org/10.1111/j.1540-6261.1988.tb04603.x

Chen, N., Richard, R., \& Stephen, A.R. (1986). Economic forces and the stock market. Journal of Business, 59, 383-403. http://dx.doi.org/10.1086/296344

Dornbusch, R., \& Fischer, S. (1980). Exchange rates and current account. American Economic Review, 70, 960-971.

El-Nader, H.M., \& Alraimony, A.D. (2012). The impact of macroeconomic factors on Amman stock market returns. International Journal of Economics and Finance, 4, 202-213. http://dx.doi.org/10.5539/ijef.v4n12p202

Engle, R.F., \& Granger, C.W.J. (1987). Cointegration and error correction: representation estimation and testing. Econometrica, 55, 251-276. http://dx.doi.org/10.2307/1913236

Fama, E.F. (1981). Stock returns, real activity, inflation and money. The American Economic Review, 71, 545-565.

Fifield, S., Power, D., \& Sinclair, C. (2000). A study of whether macroeconomic factors influence emerging market share returns. Global Economy Quarterly, 1, 315-335.

Fisher, I. (1930). The theory of interest. New York: Macmillan.

Frankel, J.A. (1993). Monetary and portfolio balance models of the determination of exchange rates. Cambridge and London: MIT Press.

Gjerde, O., \& Saettem, F. (1999). Causal relations among stock returns and macroeconomic variables in a small open economy. Journal of International Financial Markets, Institutions and Money, 9, 61-74. http://dx.doi.org/10.1016/S1042-4431(98)00036-5

Gunasekarage, A., Pisedtasalasai, A., \& Power, D. M. (2004). Macroeconomic influences on the stock market: evidence from an emerging Market in South Asia. Journal of Emerging Market Finance, 3, 285-304. http://dx.doi.org/10.1177/097265270400300304

Harvey, C.R. (1995). Predictable risk and return in emerging markets. Review of Financial studies, 8: 773-816. http://dx.doi.org/10.1093/rfs/8.3.773

Hondroyiannis, G., \& Papapetrou, E. (2001). Macroeconomic influences on the stock market. Journal of Economics and Finance, 25, 33-49. http://dx.doi.org/10.1007/BF02759685

Humpe, A., \& Macmillan, P. (2009). Can macroeconomic variables explain long-term stock market movements? A comparison of the US and Japan. Applied Financial Economics, 19, 111-119. http://dx.doi.org/10.1080/09603100701748956

Johansen, S., \& Juselius, C. (1990). Maximum likelihood estimation and inference on cointegration with applications to the demand for money. Oxford Bulletin of Economics and Statistics, 52, 169-210. http://dx.doi.org/10.1111/j.1468-0084.1990.mp52002003.x

Malik, F., \& Hammoudeh, S. (2007). Shock volatility transmission in the oil, US and Gulf equity markets. International Review of Economics and Finance, 16, 357-368. http://dx.doi.org/10.1016/j.iref.2005.05.005 
Mandelker, G., \& Tandon, K. (1985). Common stock returns, real activity, money and inflation: some international evidence. Journal of International Money and Finance, 4, 267-286. http://dx.doi.org/10.1016/0261-5606(85)90048-8

Maysami, R.C., Howe, L.C., \& Hamzah, M.A. (2004). Relationship between macroeconomic variables and stock market indices: cointegration evidence from stock exchange of Singapore's All-S sector indices. Jurnal Pengurusan, 24, 47-77.

McMillan, D.G. (2010). Present value model, bubbles and returns predictability: sector-level evidence. Journal of Business Finance and Accounting, 37, 668-686. http://dx.doi.org/10.1111/j.1468-5957.2009.02176.x

Merton, R. (1973). An intertemporal capital asset pricing model. Econometrica, 41, 867-887. http://dx.doi.org/10.2307/1913811

Mukherjee, T.K., \& Naka, A. (1995). Dynamic relations between macroeconomic variables and the Japanese stock market: an application of a vector error-correction model. Journal of Financial Research, 18, 223-237.

Muradoglu, G., Taskin, F., \& Bigan, I. (2000). Causality between stock returns and macroeconomic variables in emerging markets. Russian and East European Finance and Trade, 36, 33-53.

Solnik, B. (1983). International arbitrage pricing theory. Journal of Finance, 38, 449-457. http://dx.doi.org/10.1111/j.1540-6261.1983.tb02251.x

Tainer, E.M. (1993). Using Economic Indicators to Improve Investment Analysis. New York, USA: John Wiley \& Sons. 